\title{
Applying Evaluative Thinking to a Community-Engaged Safe Drinking Water Project in Peri-Urban Guatemala
}

\author{
Felipe Tendick-Matesanz \\ Graduate Student \\ Division of Environmental and Occupational \\ Health Sciences, \\ School of Public Health, \\ University of Illinois at Chicago \\ Felipe.T.Matesanz@gmail.com
}

Moira L. Zellner

Associate Professor

College of Urban Planning and Policy and Institute

for Environmental Science and Policy

University of Illinois at Chicago

mzellner@uic.edu

\author{
Emily Q. Ahonen \\ Assistant Professor \\ Department of Environmental Health Science and \\ Department of Social and Behavioral Sciences \\ Richard M. Fairbanks School of Public Health, \\ Indiana University \\ eqahonen@iu.edu \\ Steven E. Lacey \\ Associate Professor and Chair \\ Department of Environmental Health Science \\ Richard M. Fairbanks School of Public Health, \\ Indiana University \\ selacey@iu.edu
}

Abstract - A large number of safe drinking water programs fail to create long-lasting solutions because safe drinking water problems are complex and necessitate multiple kinds of expertise at several levels of influence over often long periods of time to succeed. Such work is especially challenging in a service-learning context. Process-oriented ways of working such as evaluative thinking and community engagement may be useful ways to frame iterative phases of work on drinking water projects. Here we describe our use of both in an interdisciplinary university student project to develop and implement collaborative plans for a safe drinking water intervention in peri-urban Guatemala, complications related to its implementation, and measures and sources of data for evaluating health, energy, and cost outcomes over time. We also assess our successes and failures to date. Though full implementation of the intervention has not been achieved and work is ongoing, we provide this report as an outline which other groups pursuing public health engineering projects may find useful.

Index terms - community engagement, evaluation, Guatemala, water quality

\section{INTRODUCTION}

Safe drinking water is essential for a healthy population; its provision a basic human right ${ }^{1}$. Safe drinking water programs tend to focus on the elimination of the health risks posed by enteric pathogens $s^{2,3}$. Unfortunately, a large number of safe drinking-water programs fail to create longlasting solutions ${ }^{4,5,6,7}$. This is the case in the developing country of Guatemala.

Guatemala has designated a large percentage of international investment to water infrastructure, but continues to struggle to maintain safe drinking-water programs. At a periurban level, projects are planned and set up with communities, which ultimately assume their management ${ }^{8}$. High poverty rates, low expenditure on public health, and unclear financial 
structure in the water sector have resulted in a population with a high level of access to improved (protected in order to limit the possibility of contamination) drinking sources, but with frequently persistent poor water quality due to problems with management of water resources (i.e., regularly functioning treatment facilities for potable water), illegal dumping and contamination, or supply that is intermittent ${ }^{7,9,10}$. Sustainability of drinking water quality -- managing water supply and achieving and maintaining physical, economic, and social infrastructure for safe drinking water now and into the future -- has been elusive, leading to high rates of diarrhea morbidity; most affected are children and the rural poor $9,11,12,13,14$.

These are not problems limited to Guatemala. Approximately 750 million people worldwide are estimated to use unimproved drinking water sources ${ }^{15}$, and the global burden of deaths from diarrheal disease which can be attributed to inadequate drinking water and sanitation in low and middle income countries has been estimated to be 685,000 for 2012 ; over $5 \%$ of the total disease burden in children under 5 years of age could be avoided by reducing risks for diarrheal disease ${ }^{16}$. From 1978-2003, the World Bank spent $\$ 5.5$ billion USD in rural water and sanitation interventions ${ }^{17}$, but the actual effectiveness of these efforts is poorly studied and little is known about what makes these interventions successful or unsuccessful ${ }^{18}$. While physical infrastructure challenges can themselves be complicated ${ }^{1,3,19}$, implementation of solutions and their sustained efficacy, critical to success and sustainability over time, can become complex. A lack of personnel knowledgeable in engineering and health, un-planned communities, unclear leadership, cultural and value systems of those who benefit from safe drinking water interventions, individual behaviors, and the resource and fiscal challenges imposed by poverty may all be barriers locally, and the extent of their combined impact on drinking water programs is not well understood $15,17,20,21,22$.

Such environmental health problems have been deemed "wicked" 23 because of the complex web of social, economic, cultural and political issues that influence what might otherwise be considered "tame" problems, or those more clearly definable and solvable by mechanistic, discipline-specific analytic means. In safe drinking water projects, ecological considerations related to water supply and use add another aspect of complexity. However, wicked problems are often informed by and comprised of many tame problems which may be understood using the tools of scientific experts and collaboration with the community ${ }^{24}$.

In considering ways to achieve sustainable management of water-related infectious diseases, a wicked problem, Batterman and his colleagues ${ }^{20}$ have suggested a systems approach, which fosters integration of differing expertise across phases of iterative problem definition, researching and choosing among alternatives to address the problem, implementing, and evaluating the effort. Such an approach recognizes that a long view of the problem is required, that its specifics will change over time, and that strategies and expertise required to solve it will evolve. If the composition of safe drinking water problems is complex, such integration across disciplines and paradigms over a sustained time period to solve them can be similarly challenging. Evaluative thinking and community engagement can help with both problems.

In evaluation, systematic, applied empirical inquiry is used to form judgments about "...the state of affairs, value, merit, worth, significance, or quality of a program, product, person, policy, proposal, or plan" 25 . In situations where evaluation is involved, evaluative thinking is "a cognitive process...motivated by inquisitiveness and a belief in the value of evidence...",26, wherein thoughtful questions are posed, assumptions are highlighted and checked, and a systematic approach to the collection, analysis, and interpretation of information is used to 
inform decisions. Evaluative thinking can also be used to build a culture of reflective practice in organizations or other groups such as ours ${ }^{27}$. This way of thinking depends not only on major principles of systematic inquiry and logic, but also on strong communication and values which are thought to lead to effectiveness in organizations and useful evaluations ${ }^{28}$. Evaluative thinking as a general approach may thus be useful to break down aspects of complexity to simpler sub-situations for which solutions can be developed ${ }^{29}$, to track progress, and to plan for subsequent iterations of work and evaluation ${ }^{30,31,32}$.

Community engagement takes many forms and exists across a continuum of intensity. In general, though, community engagement is characterized by collaboration to address issues which affect the wellbeing of that community through partnerships that harness resources and influence systems to create changes which will improve the health of the community, and is thought to be of central importance to addressing many entrenched public health problems ${ }^{33}$. Because community collaboration requires a long-term commitment by all parties, it is also an approach compatible with situations of complexity. Both evaluative thinking and community engagement are overarching ways of working rather than specific tools for assessment.

This article describes our efforts to employ evaluative thinking and community engagement principles in an ongoing safe drinking water project in peri-urban Guatemala. The work described was conducted by the Engineers Without Borders Student Chapter at the University of Illinois at Chicago (UIC-EWB). The team was comprised of students and faculty members from engineering, public health, and urban planning, in order to facilitate learning across professions and make progress on complex public health problems. Here, we describe: 1) our collaborative strategies for assessing community needs and determining solution strategies, planning for implementation of the intervention, and indicators we developed to contribute to measuring the success of the intervention over time (methods section); 2) results of an initial phase of work (results section); 3) an assessment of the strengths and weaknesses of our efforts to date (discussion section). While from an evaluation perspective, processes may also be considered results at certain phases in an ongoing effort ${ }^{24,27}$, we have arranged our narrative in the more traditional structure of a research paper. As such, the process of designing the intervention is described only in the methods section. Because full implementation of our project has not been achieved, and because work is ongoing, our purpose here is not to describe the degree to which all outcomes have been achieved. Rather, our aims are to thoughtfully track our own efforts, as well as provide an outline of our interdisciplinary work which other groups pursuing public health engineering projects may find useful.

\section{Design}

\section{METHODS}

Approval for the human subjects aspects of the work was obtained under expedited review and was granted on May 3, 2012 by the Office for the Protection of Research Subjects at the University of Illinois at Chicago (Protocol \#2012-0376). We began by considering processes, both what would be done and how we would do it. Thinking carefully about processes and documenting them is important for several reasons. First, the ways in which results are sought set the tone of collaborative efforts; that is, within a community-engaged strategy, how work is done may be as important as whether it is done. Second, processes lead to both intended and unintended outcomes; an understanding of how something does or does not work is important for maintenance of success and for adjustment of the intervention as needed to improve function and 
results. Finally, processes can also be considered actual gains (outcomes) in the intervention if they put in place practices or structures that will advance the overall efforts or make them more sustainable over time ${ }^{22,24}$. Indeed, some have suggested that the quality of the processes used to address complex problems may be important benchmarks for progress toward solving them ${ }^{19}$. Our processes were guided by principles of community engagement, which are summarized with a description of levels of engagement in Table I.

\section{TABLE I \\ CONTINUUM OF CHARACTERISTICS OF COMMUNITY ENGAGEMENT HIGHLIGHTING LEVEL OF EVOLUTION OF ENGAGEMENT IN THIS PROJECT AND EXAMPLES.}

Least engagement

Outreach - Some

Community Involvement

- One-way communication to inform

- Coexistence
Outcomes expected at this level of engagement: establish communication and outreach channels
Consult*

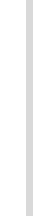

Involve*

$\mathrm{e}^{*}$

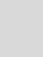

Communication to community and back for seeking information

- $\quad$ Gets feedback from community

- Information is shared

Outcomes expected at this level of engagement: Developed connections

\section{- Bi-directional, participatory communication \\ - More active participation in community on specific issues \\ - Clear cooperation}

Outcomes expected at this level of engagement: Established, visible partnership and cooperation

- Co-establishment drinking water quality as a priority

- Choice of intervention made by community

- Co-development of implementation goals and timeline with formal and informal community leaders of improvement of
Collaborate -

Community Involvement

- Bi-directional, participatory communication

- Partnership on all aspects of projects at all phases
Most engagement

Shared Leadership Strong Bi-directional Relationship

- Community makes final decisions

- $\quad$ Strong partnership structures exist
Outcomes expected at this level of engagement: Partnership and trust building
Outcomes expected at this level of engagement: Strong bi-directional trust; impact on health outcomes in the community

*Gray shading indicates level of engagement achieved during different phases of the project to date Reference: Adapted by the authors from U.S. Centers for Disease Control and Prevention ${ }^{33}$, p. 8 
We began with definition of the community's priorities, information-seeking about problems related to those priorities, and co-decision-making about how to intervene. Our process later evolved to include data provision to inform evaluation of progress, and shared control over implementation and maintenance of the intervention. For the time period leading up to the implementation of the project described here (2007-2011), the group made between one or two trips per year to the community. On the earliest of those trips the group completed projects unrelated to the current implementation effort. Later trips evolved, through relationship-building and conversations, to assessments more clearly related to the current effort. Frequency depended on the nature of the next phase of work, readiness to perform it, and fundraising. The group was consistently led by one faculty member who was present on every trip, with intermittent contentarea contribution by several others. In addition, a volunteer Professional Engineer traveled on most, but not all, occasions. Student membership varied. Three to four core student members, all of them with high-level Spanish language skills (some of them with families from Latin American countries, but none from Guatemala), were consistent contributors and points of contact with the community, and between six and eight other students without high-level language skills were more variable contributors on several trips. Trip lengths ranged from 5-12 days. Thus, in any given year, UIC-EWB would have been present in the community between five and 19 days. Between trips, communication occurred in the form of electronic mail messages or phone conversations to check in and plan for upcoming site visits.

We scoped initial concerns through structured key informant interviews with formal and informal community leaders. These included members of the recognized village leadership body, several lay community health workers, and individuals who were named as influential in the community by others. We then conducted broader health assessments between 2007 and 2008 which showed that childhood diarrhea was a major concern and contributor to the burden of illness within the village. We further found that the community believed the health burden was related to the installation of a water piping system in 2006. To identify contributors and sources of possible contamination of the water supply, we carried out multiple system and health analyses between 2007 and 2011, including community planning surveys, community health surveys, and engineering and technical analysis of the community's water system.

Findings from engineering and technical analyses have been previously reported in $\operatorname{detail}^{34}$. Briefly, initial findings concluded that water mechanically pumped from the 245 meterdeep well was easily accessed because it was delivered from a main storage tank to taps at the household level using a gravity-driven system. Delivery, however, was intermittent and thus required storage of water at the individual household level. Major reasons for intermittent household water delivery were:

- Varying pipe diameter throughout the system, which limited the pressure required to service all taps at once;

- The combination of the amount of time it took the pump in the well to fill the main storage tank, and subsequent costs in electricity required for that extended time period meant water was rationed to save money. Taps in different community sectors were allocated water at different times of the week for only a few hours;

- Limited community knowledge of infrastructure maintenance techniques;

- Lack of funding for ongoing required maintenance;

- Lack of a structure for procuring maintenance funds and a system for using them. 
Each household in the community had a cistern made of either a wood or cement frame lined in plastic with a typical total volume of about $6 \mathrm{~m}^{3}$ which was filled from the tap and used for washing and bathing and which was uncovered. Households had separate plastic containers of either 20 or $40 \mathrm{~L}$ which were filled from the tap. Containers usually had covers of some sort, but were not always observed to be used by our group. In addition, domestic and farm animals were present in the household areas around water containers. A basic chlorination system had been installed by the local government between the well supply line and the main cistern; a few $70 \%$ calcium hypochlorite tablets were left for instructional purposes. Community leadership was responsible for procuring more for the fontanero, a community member responsible for drinking water in the village.

After GPS-mapping all features of the water system and the households in the community, and displaying them over topographical maps, test sites were randomly selected while accounting for household density in different areas. Matched samples from household taps and storage containers from 28 (18\% of community households) homes were taken to determine the concentrations of four classes of indicator bacteria (aerobic bacteria, total coliform, fecal coliform and Escherichia coli), the presence of Salmonella, and total and free chlorine. Indicator bacteria were chosen because of their significance for health outcomes and were analyzed at a commercial lab in Guatemala City using standard procedures ${ }^{35}$. Geometric means for indicator bacteria were calculated. Total and free chlorine were determined in the field with a detection range of zero to ten ppm.

Microbial testing revealed that chlorination was likely not vital to maintain water quality - the protected deep well (245 meters) showed levels of each of the four classes of indicator bacteria at or below levels of detection. Non-detectable levels were also found at 25 of 28 household taps for all but aerobic bacteria concentrations. But levels of aerobic bacteria ( $<100 \mathrm{CFU} / \mathrm{mL}$ ) found do not necessarily suggest a health hazard. We found elevated levels of indicator bacteria for diarrhea in water storage containers at individual households, however, which were thus determined to be the source of contamination. Levels found in most household storage container samples were above both US Environmental Protection Agency and World Health Organization limits for total coliform, E. coli, and fecal coliform.

Results of chlorination testing showed insufficient chlorine concentrations $(<0.5 \mathrm{ppm})$ throughout the water system to deter negative health impacts. Though we initially believed that the poor water quality was only a result of insufficient funds for chlorine tablets and resultant rationing, further investigation identified an additional lack of community acceptance of treatment techniques; the use of chlorine tablets had also been reduced because residents disliked the smell and taste of chlorine.

We shared all testing results with the community at large through village meetings, with lay health promoters in the community, with community leadership, and agreed to investigate options for remediation. The professional engineer (PE) associated with our group performed an alternatives analysis for remediation. Options included using ceramic filters, chlorination, installing a larger tank, or a larger pump. Together we framed the range of options for remediation by considering both the primary preventive model preferred in public health and the hierarchy of controls strategy for establishing intervention priorities employed in industrial hygiene. These approaches both specify that strategies to intervene on a health problem should aim to prevent disease or injury in the first place, and do so by reducing harmful exposures or risk factors ${ }^{36}$. At the top of the hierarchy of possible controls for environmental hazards is the 
elimination of the hazard altogether; thereafter, replacing the hazard with something less hazardous, isolating the hazard so people cannot come into contact with it, changing the way people interact around the hazard, and providing individual barriers to the hazard are options in descending order of preference ${ }^{37}$. Such a perspective means that removing the need to store water at the household level should effectively eliminate the contamination. This analysis concluded that a larger pump was the best option for an intervention. The installation of a more efficient and powerful pump in combination with a reduced-voltage motor starter would reduce motor runtime and result in lower electrical usage through an increase in pumping rate. Elimination of water storage would remove contamination, and diarrhea burden would be reduced. In addition to the obvious benefit of hazard removal, intervening at this level does not rely on consistent and correct human behavior (such as use of chlorine tablets, hand washing, or covering of drinking water containers) to prevent illness, though primary preventive efforts may also include efforts to promote healthy behaviors and environments. Our group received approval from the community in 2011 for design upgrades to create a continuous water supply system.

\section{Implementation, Outputs, and Outcomes}

The formal and informal community leaders and our group worked together to establish goals for implementation. These included procurement of equipment, installation, establishment of an oversight committee and maintenance and operations funds. We used literature on drinking water interventions as well as known community concerns to define metrics that would help us to understand important considerations which would be obtainable over time for continued monitoring and evaluation. Because our engagement with the community demonstrated that diarrhea burden and cost were of central concern to the community, currently developed output and outcome indicators emphasize those goals. We included existing and newly collected data to inform these outcome metrics, which are described below, and summarized in Table II. 
TABLE II

\section{OVERVIEW OF MONITORING AND EVALUATION PLANS FOR AN ONGOING SAFE DRINKING WATER INTERVENTION}

\begin{tabular}{|c|c|c|c|c|}
\hline CONSIDERATION & $\begin{array}{l}\text { MONITORING } \\
\text { INDICATORS }\end{array}$ & EVALUATIVE QUESTIONS & $\begin{array}{c}\text { DATA SOURCE / OUR } \\
\text { APPROACH }\end{array}$ & $\begin{array}{l}\text { ASSESSED / } \\
\text { ACHIEVED }\end{array}$ \\
\hline $\begin{array}{l}\text { Process } \\
\text { Design }\end{array}$ & $\begin{array}{ll}\text { - } & \text { Overall community } \\
\text { input } \\
\text { - } & \text { Input of community } \\
\text { leaders } \\
\text { - } \\
\text { Analysis of } \\
\text { intervention } \\
\text { alternatives } \\
\\
\text { - } \quad \text { Equipment } \\
\text { procurement } \\
\text { Installation of } \\
\text { equipment } \\
\text { Equipment } \\
\text { functioning } \\
\text { Establishment of } \\
\text { water committee } \\
\text { Establishment of } \\
\text { maintenance \& } \\
\text { operations fund } \\
\text { Support for physical } \\
\text { maintenance, } \\
\text { including bilingual } \\
\text { service manuals and } \\
\text { logs }\end{array}$ & $\begin{array}{l}\text { How well does the } \\
\text { intervention fit } \\
\text { priorities of the } \\
\text { community? } \\
\text { Is the intervention } \\
\text { design based on } \\
\text { good engineering, } \\
\text { planning, and } \\
\text { public health } \\
\text { practices? } \\
\text { How well was the } \\
\text { intervention } \\
\text { implemented in } \\
\text { terms of ethical } \\
\text { considerations, } \\
\text { financial } \\
\text { accountability, and } \\
\text { project } \\
\text { sustainability? }\end{array}$ & $\begin{array}{ll}\text { - } & \text { Community health } \\
\text { assessment } \\
\text { - } & \text { Community planning } \\
\text { survey } \\
\text { - } & \text { Engineering/technical } \\
\text { analysis of water system } \\
\text { - } & \begin{array}{l}\text { Engineering, planning, } \\
\text { public health expert } \\
\text { review }\end{array} \\
\text { - } & \text { Memorandum of } \\
\text { - Tnderstanding } & \text { Telephone } \\
\text { communication records } \\
\text { Email communication } \\
\text { records } \\
\text { Observation }\end{array}$ & $\begin{array}{l}\text { Portions } \\
\text { ongoing }\end{array}$ \\
\hline $\begin{array}{l}\text { Outputs (short- } \\
\text { term results of } \\
\text { current } \\
\text { implementation } \\
\text { efforts) }\end{array}$ & 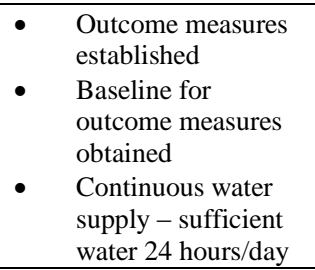 & $\begin{array}{l}\text { Were the achieved } \\
\text { outputs adequate? }\end{array}$ & $\begin{array}{ll}- & \text { Observation } \\
- & \text { Email communication } \\
\text { records } \\
\text { - } & \text { Telephone } \\
& \text { communication records }\end{array}$ & $\begin{array}{l}\text { Portions } \\
\text { ongoing }\end{array}$ \\
\hline $\begin{array}{l}\text { Outcomes (mid- } \\
\text { to long-term) }\end{array}$ & $\begin{array}{ll}\text { - } & \text { Water supply and } \\
\text { demand } \\
\text { - } & \text { Energy efficiency } \\
\text { - } & \text { Electricity costs } \\
\text { - } & \text { Diarrhea prevalence } \\
\text { by age } & \text { Diarrhea severity }\end{array}$ & $\begin{array}{l}\text { - Is energy efficiency } \\
\text { substantial enough } \\
\text { to account for } \\
\text { increased use? } \\
\text { - Is the intervention } \\
\text { economically } \\
\text { sustainable for the } \\
\text { community? } \\
\text { Is increased } \\
\text { demand for water } \\
\text { reasonably } \\
\text { balanced with other } \\
\text { outcomes? } \\
\text { Are changes in } \\
\text { diarrhea burden } \\
\text { substantial enough } \\
\text { to make a real } \\
\text { difference to } \\
\text { children's health? }\end{array}$ & $\begin{array}{ll}\text { - } & \text { Existing project } \\
\text { technical and } \\
\text { engineering documents } \\
\text { - } & \begin{array}{l}\text { Community census and } \\
\text { surveys }\end{array} \\
\text { - } \quad \text { Local electric utility } \\
\text { records } \\
\text { - } \quad \text { Informal active } \\
\text { surveillance data from } \\
\text { lay community health } \\
\text { workers records } \\
\text { Department of Public } \\
\text { Health records }\end{array}$ & Ongoing \\
\hline
\end{tabular}




\section{Water supply}

We used data from existing UIC-EWB engineering and technical documents from earlier phases of collaboration with the community to consider household water demand at an earlier phases of collaboration (26 gallons/person/day*population total=total daily demand), the flow rates of the old pumps (at best function could provide 109 gallons /minute), estimated flow rate of the new pump (150 gallons/minute), number of water taps (a count), and reservoir volume (11,478 gallons). Census and survey data used to predict population growth for diarrhea prevalence data were used to predict population growth to 2022. Future demand was estimated using the average daily use estimates of water predicted in UIC-EWB technical documents and multiplied by population growth expectations. Though most future worldwide population growth is predicted in urban areas and this setting is best described as peri-urban, our observation and information provided by the community suggested ongoing population growth. As such, we felt it important to estimate future growth as best we could by using the growth we had been able to observe.

\section{Energy efficiency}

To measure the energy efficiency of the newly installed pumping system we divided total energy consumption by time (also known as kilowatt-hours(kWh)). Electricity data were acquired from the local utility, EnerGuate. Data were organized by bill date and consumption $(\mathrm{kWh})$ per month, and assessed using trend analysis of consumption from December of 2010 through October of 2012, measuring mean monthly difference by year.

\section{Electricity costs}

We obtained six months (April - September 2012) of photocopied electricity bills maintained by a community leader, which allowed us to assess costs for running the new pump.

\section{Diarrhea burden}

The regional Department of Public Health (DPH) has a passive surveillance system of reportable diseases, similar in design to the system in the United States. Information on reportable diseases is documented by location, and reported as overall case counts for the entire year. Cases are reported to DPH from clinics in the village, which are run by a government-hired nongovernmental organization. Every week the clinics notify cases of diarrhea treated to the central government. We created a standardized data extraction form and acquired aggregate data for the village from an epidemiologist at the DPH. Data showed cases of diarrhea occurrence by year, month, and age group (0-6 years, 7-15 years, $>15$ years). We could not determine whether or not these cases were laboratory confirmed, what tests were performed, or if case definitions were used. Because these cases are garnered from a formal clinical setting, they are likely to represent more severe cases.

We also included data from an informal active surveillance program (IASP) in the community. The IASP was instituted by members of the community known as promotor/a $(s)$ and vigilante $(s)$, who practice natural and/or traditional medicine. All records of encounters with the promotor/a $(s)$ are maintained by one community member. Using a standardized data extraction form, she provided aggregate data of occurrence of diarrhea by year, month, age group (same as DPH), sex, and severity. Case definitions were determined by the promotor/a(s) for children as follows: (1) mild: non-continuous watery stools were identified; (2) moderate: dehydration is 
obvious, and (3) severe: unable to keep in liquid and foods. Adult case definitions were provided to the promotor/a $(s)$ by the patient.

We acquired data on the overall population of the community from the Instituto Nacional de Estadística (INE) and UIC-EWB records. The INE conducts a national census every ten years. Data are acquired by INE through household surveys identifying number of people in each household, age, gender, ethnic group, literacy level, education, and employment by gender. Data for the 2012 census were not yet available, so we used Census data and between-Census estimates from 1994, 2002, and 2006 numbers as a start. The UIC-EWB then carried out two separate surveys to use in population growth estimation. The first was conducted in 2009 through a random sample of 27 homes identifying head of household, number of people in each household, age, gender, and family relationship of each member of household. This methodology was repeated in 2012 with a sample size of 32 . All census and survey data were combined, and we used these five data points for linear and exponential regression to estimate population and proportion of population by age group from 2009-2012.

These data were used to estimate period prevalence, which is a measure of the presence of an illness or disease state in a population over a defined period of time (here, number of reported cases of diarrhea in a month / average reference population for the same period). We plotted the monthly prevalence on a graph in order to assess patterns and changes in diarrhea occurrence over time.

\section{RESULTS}

\section{Implementation, Outputs, and Outcomes}

We secured hardware for the upgrade through donation, and implementation of this project began in January of 2012. Our group traveled to Guatemala and during this trip, like others, a meeting was held between the entire EWB-UIC team and the twelve members of the recognized village leadership council. The topics discussed included objectives for the trip, the community's needs and concerns, and the pump installation schedule; a major goal of this trip was to assist local technicians with installation of equipment, but the high-capacity pump did not arrive during the implementation trip because of delays in shipping and customs. It was not installed during our trip, and as such testing of continuous flow did not occur. Figure I shows a timeline of events from the implementation trip to the full function of the pump. Though the pump is functioning, the system as a whole is not; continuous water supply had not been achieved at the time of this writing. 


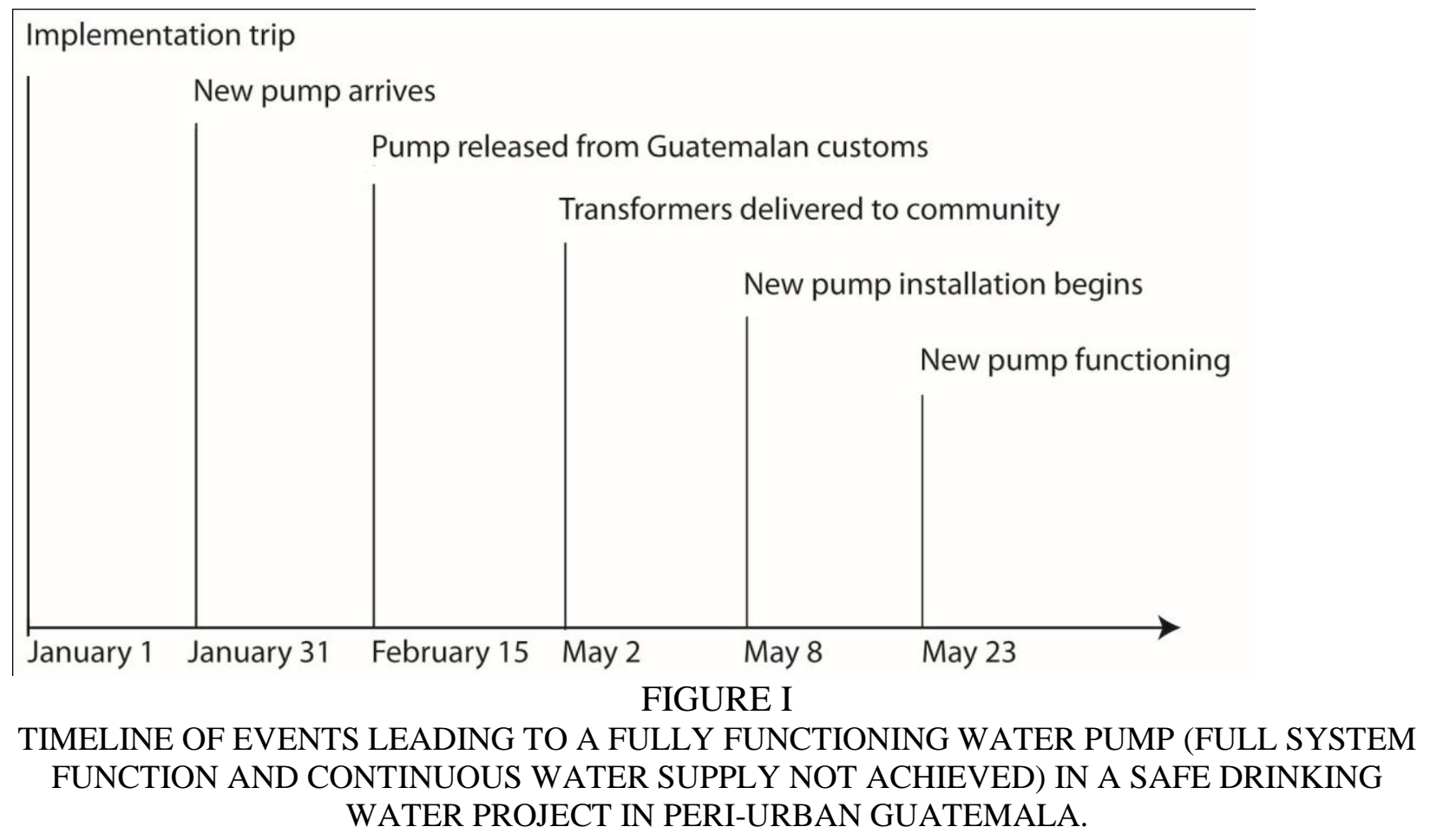

On that trip, the community leadership group formed a water committee of five representatives from the different sectors of the village. The village leadership also communicated their concerns about the existing flat-rate water pricing schedule and inquired about the implementation of water metering. The community believed that water metering at the household level would encourage responsible use. EWB-UIC suggested metering the well withdrawals as well in order to quantify losses in the water system. Two days later, UIC-EWB met with the newly formed water committee to further discuss the maintenance fund, operations and maintenance details, and our common goals for work in the next few months. UIC-EWB sent follow-up materials and instructions on daily documentation of activities, establishing a maintenance fund, a checklist and what to consider with each item of testing a continuous system (including where to install pressure reducing valves), and a roles and responsibilities plan for the water system.

As of September of 2012, the operations and maintenance (O\&M) fund had not been created. The community relies heavily on government subsidies for electricity, which covers only portions of its monthly electricity bills to run the water system. The recognized leadership body set up a flat rate, tiered payment system charged to households monthly for access to water. The tiers discount service for low-income residents in special circumstances, such as widows. The recognized leadership body had convened several times, and had begun planning for the development of an O\&M fund. The agreement was to build the fund through a monthly addition of 0.64 USD per user, which would be overseen by the water committee. At this writing, the official community leadership was questioning whether the water committee, not recognized at a governmental level, had authority to oversee such a fund. 
Water supply

Prior to intervention, there were 204 household connections to waterlines with an estimated 1,050 residents. On average, 26 gallons were needed daily for consumption per person. To fulfill current needs of the community, a minimum of 27,300 gallons would be needed per day. In 2022, an estimated population of 1,385 would require 36,010 gallons per day. The main water tank has an estimated capacity of 11,477.8 gallons. The original pump system was comprised of two pumps that had a combined flow rate of 109.2 gallons per minute (GPM). Often only one pump was used, for a flow rate of 67.6 GPM (single tank fill time 2.83 hours, double pump fill time 1.75 hours). The original pump systems combined had a flow rate which was insufficient, meeting daily demand in 4.17 hours $(27,300 \mathrm{~g}$ [current demand] / $109.2 \mathrm{~g} / \mathrm{m}$ [combined flow rate $]=250 \mathrm{~g} / \mathrm{m} ; 250 \mathrm{~g} / \mathrm{m} / 60 \mathrm{~m} / \mathrm{hr}=4.17$ hours). Inflow into the water reservoir was less than outflow. The longer the period of time the pump was running to fill the main water tank, the greater the costs in electricity to the community.

The newly installed pump's flow rate is $150 \mathrm{GPM}$, which fills the tank in 1.28 hours. In 2022 , it could meet demand and would take 5.5 hours. The new pumping system should meet current daily demand in 3.03 hours, and 2022 demand in 4 hours. Outflow from the tank is 112.65 GPM. The new pumping system's flow rate is sufficient-inflow into the water reservoir is greater than outflow and allows for 24-hour use. Our most recent correspondence with community members indicates that the high-capacity pump and two transformers have been installed, but the float tank switch and pressure reducing valves have not, and the distribution pipes have not been buried because of a decision to upgrade roads to the community. Water is still being supplied intermittently.

Energy efficiency and electricity costs

Energy consumption of the newly installed pump was lower than overall averages prior to its installation (Figure II). While energy consumption went down, monthly costs went up and are at the highest since January of 2011 (Figure III). Bills from April to September revealed that the rate at which energy consumption was charged (dollars/kWh) increased from 0.12 USD to 0.14 USD to 0.16 USD. We were unable to obtain data about the rate charged prior to this time period. 


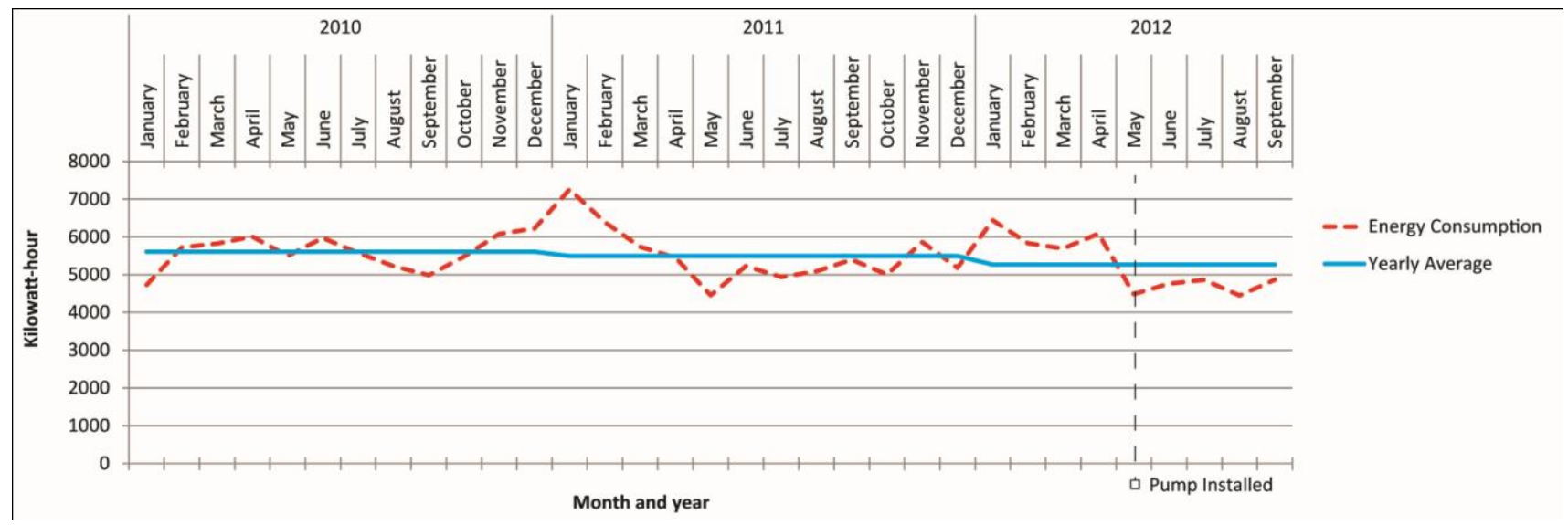

FIGURE II

ELECTRICITY CONSUMPTION IN KILOWATT HOURS IN A VILLAGE IN PERI-URBAN

GUATEMALA.

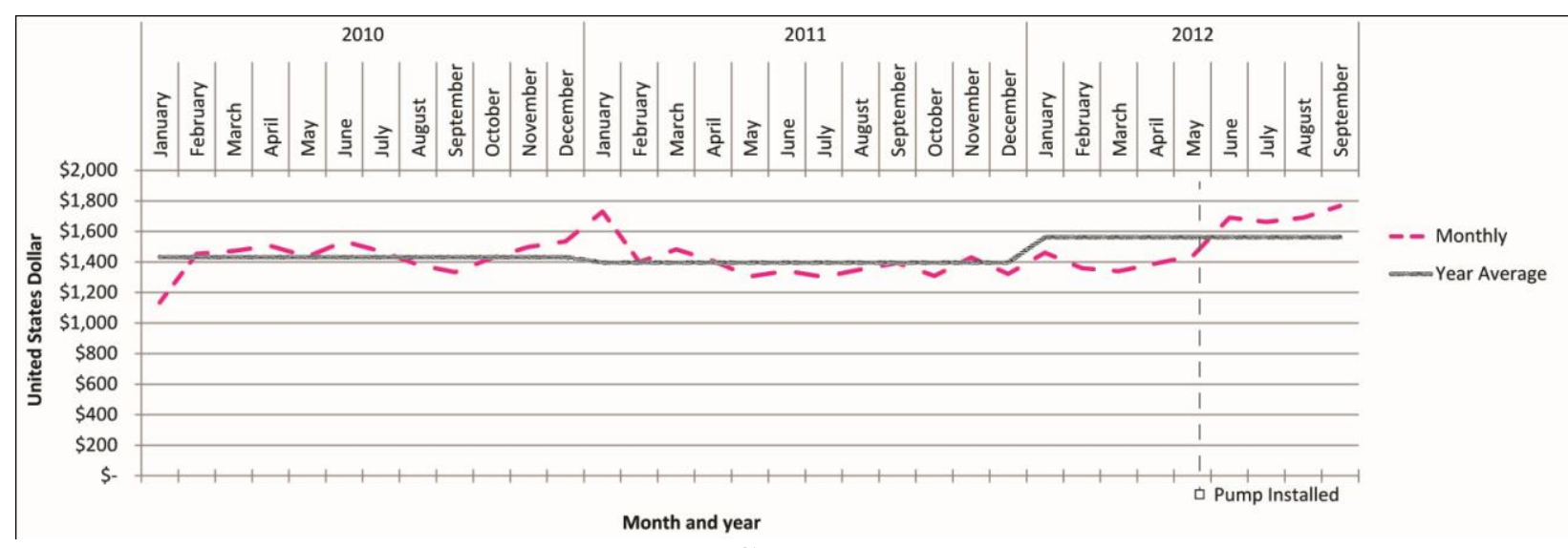

FIGURE III

WELL PUMP ELECTRICITY COSTS IN A VILLAGE IN PERI-URBAN GUATEMALA

\section{Diarrhea burden}

Though prevalence rates derived from the lay community health worker's data were quite a bit higher overall than DPH prevalence rates (reflecting the fact that the DPH sees the most severe cases), our analyses showed that there was reasonable trend agreement between the prevalence estimated from the DPH's total documented monthly cases of diarrhea and the prevalence estimates calculated from diarrhea cases reported by the lay community health worker (Figure IV). Figure V, using lay community health worker data, suggests that the newborn through 6year age group was affected at a higher rate than other groups (the 'all age groups' trace is not the highest one in this figure because prevalence estimates account for population size). Over the past three years this group totaled approximately 20 percent of the population and suffered 70 percent of the diarrheal burden. The highest number of cases occurred in the mild category (Figure VI). Diarrhea ocurrence in the community fluctuated year to year with peaks during the wet seasons (Figures IV, V, VI). 


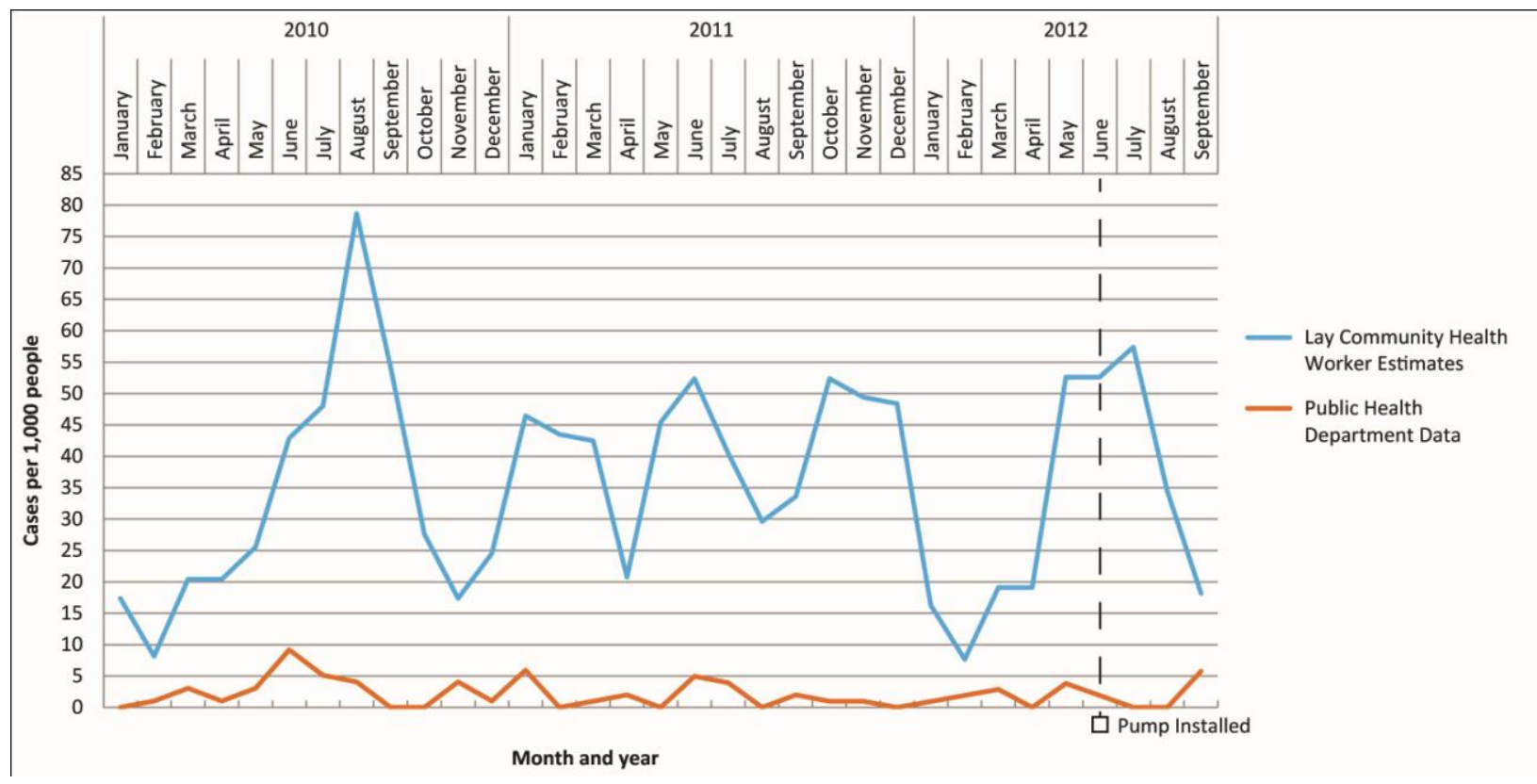

FIGURE IV

SEVERE DIARRHEA PREVALENCES FROM TWO DIFFERENT REPORTING SOURCES IN A VILLAGE IN PERI-URBAN GUATEMALA.

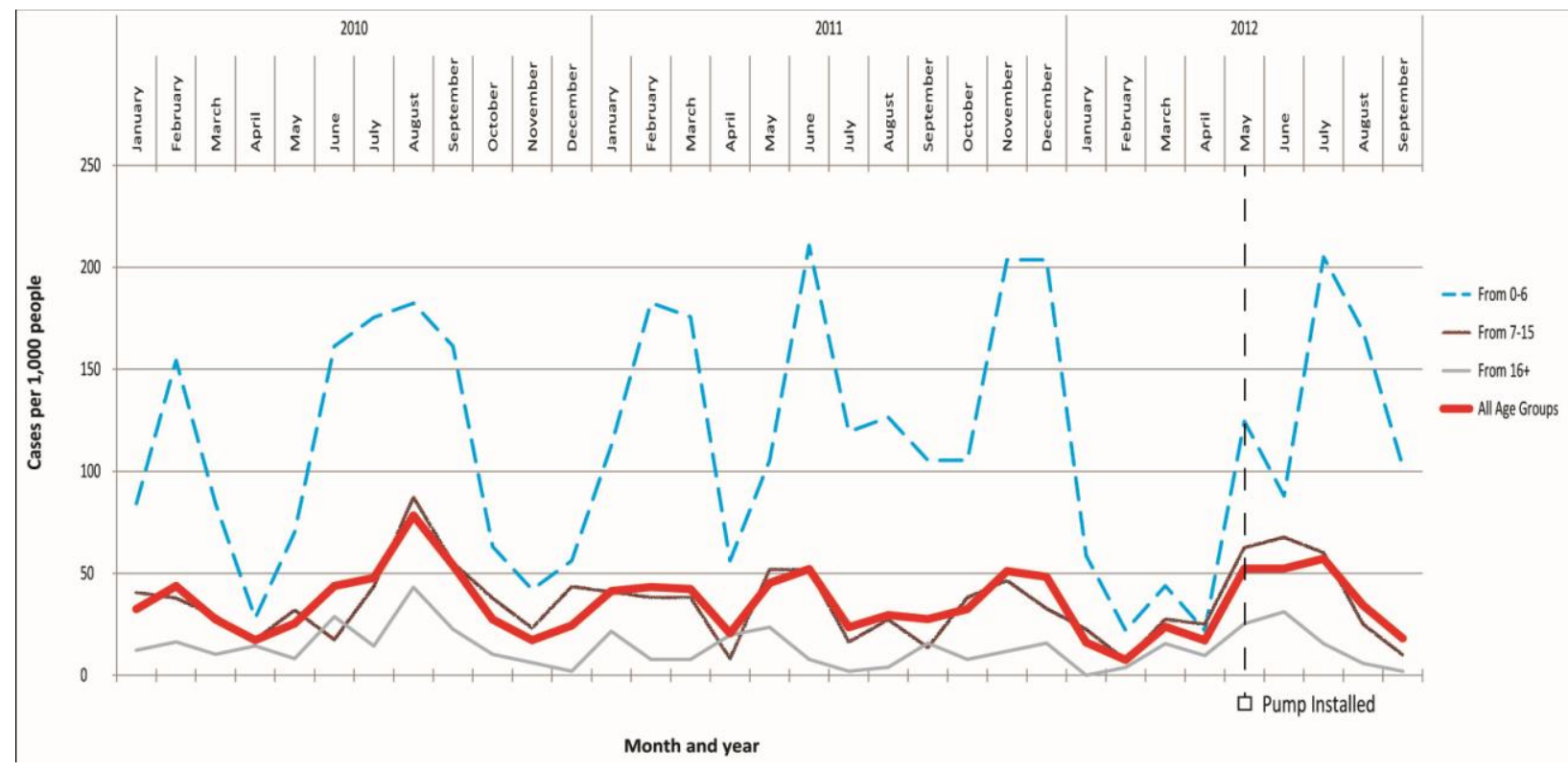

FIGURE V

PREVALENCE OF DIARRHEA BY AGE GROUP REPORTED BY LAY COMMUNITY HEALTH WORKER IN A VILLAGE IN PERI-URBAN GUATEMALA. 


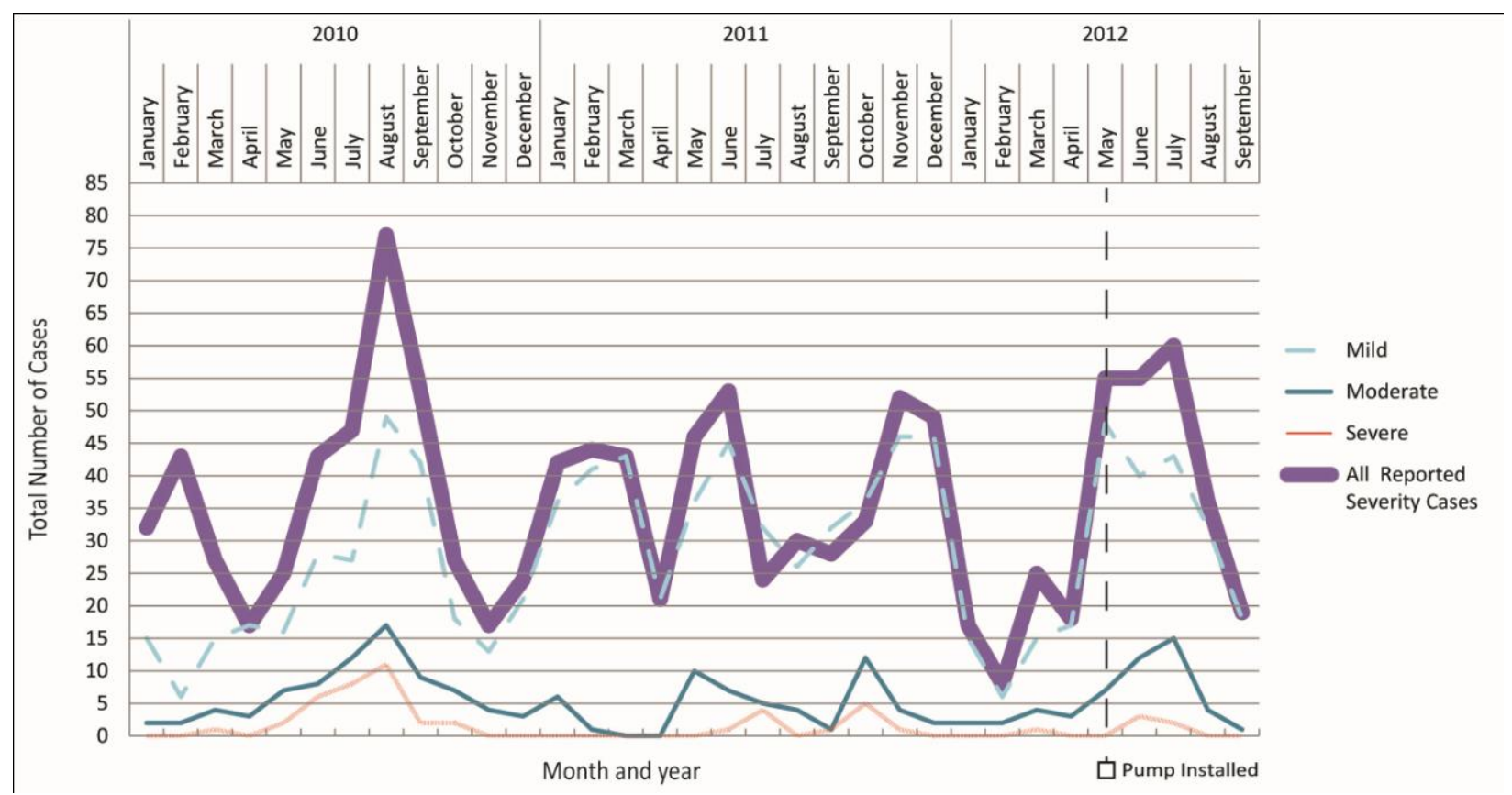

FIGURE VI

SEVERITY OF DIARRHEA CASES REPORTED BY LAY COMMUNITY HEALTH WORKER IN A PERI-URBAN VILLAGE IN GUATEMALA

\section{Design}

\section{DISCUSSION}

Matters of most importance to the community were reducing the burden of childhood diarrhea, and doing so through installation of a water system whose capacity would incur affordable electric costs. We therefore used both community input and expert review from three fields (engineering, planning, and public health) to design an intervention that would reduce diarrhea burden by eliminating household-level water storage through continuous household water supply. Because the system would be more efficient, increases in cost were planned to fund a maintenance and operations budget for the system. As designed, the intervention is a very good fit with community desires and good professional practices.

\section{Implementation and Outputs}

While delayed, installation of the pump and transformers nevertheless were accomplished. Other aspects of the water system (float tank switches, pressure-reducing valves, burying pipes) have not been fully implemented. In an example of complexity related to the implementation of this intervention, a regional-level decision to embark upon a road-upgrade project meant that the pipes have not been buried. Because the community leadership does not have complete control over this initiative, effort at moving this aspect of the project forward has stalled.

Though a water committee was established to oversee the system and its maintenance, a supporting fund has not been established, which represents failure to achieve an important goal. This seems to be related, at least in part, to strained relationships between members of the community leadership and members of the water committee, which may in turn have slowed 
down the development of required human and monetary infrastructure for maintenance. We observed ongoing challenges to the ability of the two groups to work together effectively. In one instance, for example, members of the community leadership body declined to offer assistance in acquiring public health data on diarrhea from the DPH on the grounds that this was the responsibility of the water committee. This occurred after the leaders had signed a letter of support stating that, as the legally recognized community leadership group, they would assist in acquiring these public data. While that problem was related to the acquisition of data, our communications and observational data suggest that similar undermining may also be hindering the work of the water committee to develop appropriate human and financial infrastructure to fully implement and support the water system. If they continue, the lack of cooperation and resources will seriously limit the full implementation of the intervention, and the sustainability of those aspects which have been implemented.

We were successful in establishing baseline measures of efficiency, cost, trends through time, consumer water demand, and diarrhea burden, which may be used as the project moves forward. These measures will allow a fuller estimation of value of the intervention over time; such factors are often ignored in the drinking-water evaluation literature, as they fall outside the scope of a purely engineering-focused intervention ${ }^{4,7}$. Furthermore, our examination of baseline information on diarrhea prevalence in the community addressed a central community concern and highlighted the reliability of the community health workers as a data source for assessing future health outcomes. In ongoing monitoring, these local data may be important for their ready accessibility. While a formal surveillance system exists at the health department, data available from the informal, active surveillance in the village may make the identification of water system problems faster, allowing a more nimble response. These outputs were adequately achieved. However, continuity of water supply, an output which is centrally related to the progress of improving health outcomes, has not been achieved.

\section{Outcomes}

It is important to account for expected population change trends when determining the capacity required of a water system. In this instance, we created and implemented a community planning survey to determine current and future demand for water between government census counts. The newly installed system has sufficient capacity to meet current and future estimated demand. However, in addition to observed and reported growth in the community associated with its location near a mid-sized city, increased capacity also invites growth, which may reach levels which are unsustainable in terms of economic capacity of the community and available natural resources. Ongoing evaluations of monitored indicators will need to explicitly consider the balance of potential desired outcomes, such as reduced diarrhea burden and greater efficiency of the water system, with undesired outcomes such as unchecked demand on the water supply. One option to counteract unchecked growth is to charge residents for water use, rather than at a flat rate, which may prompt more considered water use. This option will have to be balanced against the economic constraints of the community, and considered in combination with education on water conservation strategies. Discussions about these concerns were ongoing with the community at the time of this writing.

While the system is more efficient in terms of cost per unit output of water, user fees were the highest they had been during the past three years, despite the fact that users were not charged the full amount agreed upon to fund an operations and maintenance account ( 0.12 and 
0.14 USD, compared to a planned 0.64 USD). We were not able to ascertain why electricity costs reached the levels they did. The community has informed us that electricity bills account only for the well pump; however, kilowatt demand is higher than the maximum demand of the new pump, indicating that another source is adding to the power use. At this writing we have been unable to identify the source of this demand. Ongoing efforts in education and communication will need to address the unaccounted for increases in demand, as well as the need to increase costs per user to agreed-upon levels in order to maintain the system. In addition to economic questions, community satisfaction will be strongly tied to maintenance of the intervention going forward. As such, this aspect of the intervention requires serious effort in order to achieve full value.

Finally, monitoring of the diarrhea burden in the community is feasible. It is too early in the intervention to draw conclusions about this outcome, as continuous water supply has not been achieved. Ongoing monitoring and evaluation will need to consider any observed changes in diarrhea burden in terms of their ability to contribute substantially to the health status of the children in the community.

\section{Limitations}

We have provided an example of how to apply evaluative thinking to a drinking water program in a dynamic setting. Monitoring processes and setting up measures to assess ongoing outcomes helped identify social and economic factors that may heavily influence future implementation efforts and project sustainability. As such, we believe this framework is a valuable one.

However, our work also has several limitations. Most of the data presented here were obtained through months of follow-up via email and telephone conversations with community leaders and keepers of governmental data, rather than acquired while in the field. In an ideal setting, some monitoring would be conducted by the water committee and the community health workers; future education and training efforts will be required to achieve this. In addition, because of the need to protect personal and medical information, we were only able to obtain health data in aggregate form. This means that while the number of cases of diarrhea is generally high, there is no way of knowing how many were repeat cases and how much this affects overall monthly prevalence.

As seen in Table I, our collaboration with the community was at the low to medium part of the engagement spectrum, and was influenced by the physical distance between Chicago and Guatemala, the consistency and composition in membership of the UIC-EWB group, and available funds for travel and other resources. Since the time period described here, the UICEWB chapter was closed, and another student chapter was connected with the community in Guatemala. These developments speak to the challenges of international service learning endeavors which can be added to the existing challenges of safe drinking water interventions.

Based on our experience, in future iterations of this project, we argue for continued general framing of work through community engagement and an evaluative lens. However as relationships with the community and between the community and the new EWB group evolve, progress toward improved outcomes (Table II) may best be achieved and assessed by a more specific framework for community engagement. Community based participatory research (CBPR), which facilitates trust among partners, incorporates and values multiple forms of evidence in research, provides a common language for community and academic collaborators, and shifts the traditional power balances (north-south, indigenous-majority ethnicity, male- 
female, formal educational attainment) through bi-directional learning, sharing of all resources, collective decision-making, and mutual benefit, is also recognized as a valuable framework for achieving sustainability of intervention and partnerships ${ }^{38,39}$. These principles also provide a common approach for groups diverse in formal education, type of education, national, cultural and linguistic backgrounds, geographic location, and scales of infrastructure to work together as equals to address challenges at the interface of human and environmental need. Several questions remain within this project, and may be well-addressed using such a framework.

In addition to working through a more engaged framework, the use of specific tools for assessment of progress are likely to be valuable in upcoming phases of work to organize and frame measures we have developed here. For example, McConville and Mihelcic ${ }^{40}$ developed a matrix tool based upon international development literature which can be used for planning purposes as well as for quantitatively scoring aspects of the intervention in terms of its sustainability. Similarly, Schweitzer and Mihelcic ${ }^{41}$ developed and tested a specific tool to assess the ability of rural communities to manage their own water systems in the developing world. Both the specific measures we have described and the information we have garnered from current levels of community engagement are compatible with the iterative approaches those authors describe.

In summary, next steps should include:

- Engaged processes to better understand the challenges between the formal community leadership and the water committee and develop solutions;

- Address remaining aspects of implementation. This should include building maintenance funds for operations of the water system, and metering of both individual and communal water use as a way to control use. These practices will have implications for the sustainability of the intervention.

- Once continuous supply begins, assess community perspectives on the new system, their ability to financially maintain it and to keep it in good repair, and water conservation education.

- Efforts to increase the level of community engagement between the EWB group and the community, which should likely include the possibility of more frequent visits and additional targeted capacity-building.

- Assessment of water supply. The quantity of water which feeds the well and its origin are not known at this time, and knowledge about these factors should be considered in decisions about future community water use.

- Develop and implement education programs to promote knowledge transfer for local monitoring and evaluation, including conducting a census, using rates and measuring diarrhea trends, and mapping incidence of diarrhea in a community.

\section{CONCLUSION}

There are many challenges in implementing international safe drinking-water projects, even in cases where community support, technical ability, and funding are in place. Student service learning groups face additional challenges of focus, time, distance and, in many cases, linguistic and cultural divides between their group and the community group. All these things mean that safe drinking-water programs are often both complicated and complex. Evaluative thinking that 
involves the affected community in careful consideration of process and provides reasonable ways to assess outcomes over time can aid in working through complication and begin to consider complexity in order to adequately measure effectiveness and impact.

\section{ACKNOWLEDGMENT}

We are grateful to the community members who gave of their time and resources to work on this project, as well as to the University of Illinois at Chicago Engineers Without Borders student chapter members and other volunteers. Our article also benefitted from two anonymous reviewers who provided useful suggestions for improvement.

\section{REFERENCES}

\footnotetext{
${ }^{1}$ Resolution A/RES/64/292. United Nations General Assembly, July 2010

${ }^{2}$ Institute of Medicine of the National Academies, Global Environmental Health: Research Gaps and Barriers for Providing Sustainable Water, Sanitation, and Hygiene Services (Washington, DC: National Academies Press, 2009).

${ }^{3}$ World Health Organization, "A public health perspective for establishing water-related guidelines and standards." Chap. 11 in Water Quality Guidelines, Standards, and Health: Assessment of Risk and Risk Management for Water-Related Infectious Disease (Geneva: World Health Organization, 2001), 229-56.

${ }^{4}$ E.J. Lee, K. J. Schwab, "Deficiencies in drinking water distribution systems in developing countries," Journal of Water and Health 3, no.2 (2005), 109-27.

${ }^{5}$ E. Miguel, M. Gugerty, "Ethnic diversity, social sanctions, and public goods in Kenya." Journal of Public Economics 89, no. 11-12 (2005),2325-2368.

${ }^{6}$ A.P. Zwane, M. Kremer, What Works in Fighting Diarrheal Diseases in Developing Countries? A Critical Review. (Cambridge: Harvard University Press, 2007).

${ }^{7}$ P.R. Hunter, D. Zmirou-Navier, P. Hartemann, "Estimating the impact on health of poor reliability of drinking water interventions in developing countries," Science of Total Environment 407 no.8 (2009), 2621-24.

${ }^{8}$ M. del Rosario Navia, R. Gomez, M. Ballestero. "Access to Water and Sanitation for All and the Right to Water in the American Region", Policy Paper, Inter-American Development Bank \& United Nations Program for Human Settlements, ( IRB \& UN-Habitat, 2011),1-82.

${ }^{9}$ T.R. Spillman, L. Waite, T. C. Webster, J. Buckalew, H. Alas, "Water Resources Assessment of Guatemala," (Doral: US Army Corp of Engineers, 2000), 1-50.

${ }^{10}$ V. Moscoso, El Sistema de Salud en Guatemala, 3: Retratos de muertes evitables., Edited by Amanuense Editorial-Grupo Amanuense. (Guatemala: Programa de las Naciones Unidas para el Desarrollo, 2008).

${ }^{11}$ O. Drakenberg, D. Slunge, "Poverty and environment in Guatemala-input to the Swedish cooperation strategy", Policy Brief, environmental Economics Unit (EEU), Department of Economics, Göteborg University, (GÖTEBORG: Sida-EEU, 2006), 1-8.

${ }^{12}$ World Health Organization, World Health Statistics, 2006. http://www.who.int/whosis/mort/profiles/mort_amro_gtm_guatemala.pdf (accessed October 12, 2011).

${ }^{13}$ World Health Organization, Global Health Observatory, Guatemala: Health profile, 2012. Geneva.

${ }^{14}$ Programa de las Naciones Unidas para el Desarrollo, "Guatemala: Hacia un Estado Para el Desarollo Humano", Government Report on Status of Nation, (Guatemala: Informe nacional de Desarrollo Humano, 2010), 145-189.
} 
15 "WHO/UNICEF Joint Monitoring Programme for Water Supply and Sanitation", World Health Organization \& United Nations Children's Fund, Accessed May 20, 2015, http://www.wssinfo.org/dataestimates/tables

${ }^{16}$ A. Prüss-Ustün, J. Bartram, T. Clasen, J.M. Colford, O. Cumming, V. Curtis, S. Bonjour, A.D. Dangour, J. De France, L. Fewtrell, M.C. Freeman, B. Gordon, P.R. Hunter, R.B. Johnston, C. Mathers, D. Mäusezahl, K. Medlicott, M. Neira, M. Stocks, J. Wolf, \& S. Cairncross. "Burden of disease from inadequate water, sanitation and hygiene inlow- and middle-income settings: a retrospective analysis of data from 145 countries". Tropical Medicine and International Health 19,8 (2014), 894-905.

${ }^{17}$ P. Iyer P, J. Davis, E. Yavuz, "Rural water supply, sanitation, and hygiene: A review of 25 years of World Bank lending (1978-2003)," Water Supply and Sanitation Working Notes, Note \#10. (Washington, DC: The World Bank, 2006). Online at: http://www.worldbank.org/watsan.

${ }^{18}$ C.K. deWilde, A. Milman, Y. Flores, J. Salmerón, I. Ray, "An integrated method for evaluating community-based safe water programmes and an application in rural Mexico." Health Policy and Planning 23, (2008), 452-64.

${ }^{19}$ P.R. Hunter, A. M. MacDonald, R. C. Carter, "Water Supply and Health." PLoS Med 7, issue 11(2010), $1-9$.

${ }^{20}$ S. Batterman, J. Eisenberg, R. Hardin, M.E. Kruk, M.C. Lemos, A.M. Michalak, B. Mukerjee, E. Renne, H. Stein, C. Watkins, M.L. Wilson, "Sustainable control of water-related infectious diseases: A review and proposal for interdisciplinary health-based systems research", Environmental Health Perspectives, 117,7, (2009), 1023-32.

${ }^{21}$ H. Waddington, B. Snilstveit, H. White, L. Fewtrell. Water, sanitation, and hygiene interventions to combat childhood diarrhoea in developing countries., (New Delhi: International Initiative for Impact Evaluation, 3ie, 2009).

${ }^{22}$ J. Eisenberg, J. Scott, T. Porco, "Integrating Disease Control Strategies: Balancing Water Sanitation and Hygiene Interventions to Reduce Diarrheal Disease Burden." American Journal of Public Health 97 , 5 (2007), 846-52.

${ }^{23}$ H. Rittel, M. Webber, "Dilemmas in a general theory of planning," Policy Sciences 4, (1973), 155-69.

${ }^{24}$ M. Kreuter, C. De Rosa, E. Howze, G. Baldwin, "Understanding Wicked Problems: A Key to Advancing Environmental Health Promotion." Health Education and Behavior 31, 4 (2004), 441-52.

${ }^{25}$ Fournier, D.M., "Evaluation", in Encyclopedia of Evaluation, (Thousand Oaks: Sage Publications, Inc., 2005a), p. 140.

${ }^{26}$ T. Archibald, \& J. Buckley, October 19, 2013, "Evaluative Thinking", presentation archived in the American Evaluation Association Public Library, accessed May 20, 2015, http://evalcentral.com/2014/10/10/evaluative-thinking-at-aea2014/

${ }^{27}$ Bruner Foundation, Effectiveness Initiatives, "Evaluative Thinking”, Accessed May 22, 2015, http://www.evaluativethinking.org/evalthink.html

${ }^{28}$ M.Q. Patton, Utilization-Focused Evaluation, (Los Angeles: Sage Publications, 2008), p. 154.

${ }^{29}$ M.Q. Patton, Developmental Evaluation: Applying Complexity Concepts to Enhance Innovation and Use, (New York: The Guilford Press, 2011).

${ }^{30}$ M.Q. Patton, Qualitative research and evaluation methods, 3rd edition, (Thousand Oaks: Sage Publications, Inc., 2002).

${ }^{31}$ N.J. Thompson, H.O McClintock, Demonstrating your program's worth: A primer on evaluation for programs to prevent unintentional injury ( Atlanta: National Center for Injury Prevention and Control, Centers for Disease Control and Prevention, 1998).

${ }^{32}$ E.J. Davidson, Evaluation Methodology Basics: The Nuts and Bolts of Sound Evaluation, (Thousand Oaks, California: Sage Publications, 2005).

${ }^{33}$ United States Department of Health and Human Services, Centers for Disease Control and Prevention, Principles of Community Engagement (second edition). NIH Publication No. 11-7782, (2011) , 7. 
${ }^{34}$ S.E. Lacey, R. Lopez, C. Frangos, A. Khodadoust. 2011. "Water Quality Degradation after Water Storage at Household Level in a Piped Water System in Rural Guatemala," International Journal for Service Learning in Engineering 6 (1), (2011), 118-29.

${ }^{35}$ S.E. Lacey, (2011), p.7

${ }^{36}$ Bernard J. Turnock, Public Health: What It Is and How It Works, $4{ }^{\text {th }}$ Edition, (Sudbury: Jones \& Bartlett Publishers, 2009), p. 112.

${ }^{37}$ United States Department of Health and Human Services, Centers for Disease Control and Prevention, "Hierarchy of Controls", Acessed May 22, 2015, http://www.cdc.gov/niosh/topics/hierarchy/

${ }^{38}$ N. Wallerstein, B. Duran B "Community-based participatory research contributions to intervention research: the intersection of science and practice to improve health equity," American Journal of Public Health, 100 (Suppl 1), (2010), S40-46.

${ }^{39}$ B.A. Israel, A.J. Schulz, E.A. Parker, A.B. Becker, "Review of Community-based research: Assessing partnership approaches to improve public health," Annual Review of Public Health, 19 (1998), 173-202.

${ }^{40}$ McConville, J.R., and J.R. Mihelcic, "Adapting Life Cycle Thinking Tools to Evaluate Project Sustainability in International Water and Sanitation Development Work," Environmental Engineering Science, 24(7):937-948, 2007.

${ }^{41}$ R.W Schweitzer, J.R. Mihelcic, "Sustainability Analysis of Community Managed Water Systems in the Developing World," Journal of Water, Sanitation and Hygiene for Development, 2(1):20-30, 2012. 